\title{
Pengaruh Kitosan Iradiasi Terhadap Fermentabilitas dan Kecernaan (In Vitro)
}

The Effect of Irradiated Chitosan on Fermentability and Digestability

\author{
I.R. Rumata*, D. Darwis ${ }^{1}$, K.A.Kamil ${ }^{2}$ \\ *Mahasiswa Magister Ilmu Ternak, Program Pascasarjana, \\ Fakultas Peternakan Universitas Padjadjaran \\ Kampus Jatinangor Jl. Raya Bandung-Sumedang Km. 21, Sumedang, \\ Jawa Barat, 45363 \\ 1Pusat Aplikasi Isotop dan Radiasi (PAIR), Badan Tenaga Nuklir Nasional, \\ Jl. Lebak Bulus Raya No. 49, Jakarta 12440 \\ ${ }^{2}$ Departemen Nutrisi Ternak dan Teknologi Pakan, Fakultas Peternakan \\ Universitas Padjadjaran Kampus Jatinangor Jl. Raya Bandung-Sumedang Km. 21, \\ Sumedang, Jawa Barat, 45363 \\ "Korespondensi E-mail : rumata_ir67@yahoo.com
}

\begin{abstract}
ABSTRAK
Penelitian pengaruh kitosan iradiasi terhadap kinerja fermentabiltas dan kecernaan bahan organik dan bahan kering telah dilakukan teknik in vitro. Seperangkat alat dan bahan in invitro telah disiapkan untuk menguji level pemberian kitosan iradiasi dalam ransum konsentrat. Level kitosan telah diuji dengan 6 pelakuan, yaitu tanpa kotosan, 300 ppm; 350 ppm, 400 ppm, 450 ppm dan 500 ppm kitosan iradiasi dalam ransum. Data yang diperoleh telah dianalisis dengan mengguanakan uji polinomial orthohonal dan kontras orthogonal, menggunakan SPPS IBM 21. Hasil penelitian menunjukkan bahwa laju fermentabilitas dan kecernaan bahan keriang dan organik berbeda nyata lebih tinggi hingga panambahan kitosan iradiasi $450 \mathrm{ppm}$. Disimpulkan bahwa kitosan hingga $450 \mathrm{ppm}$ mampu mensimulasi kerja mikro rumen dalam profes biokomiawi fermentasi dan kecernaan di dalam rumen secara in vitro.
\end{abstract}

Kata kunci: Rumen, Kitosan Iradiasi, In vitro

\begin{abstract}
The Experiment obout the effect of irradiated chiotosan (IC) on the fermentabilty and digestibility were conducted by in vitro tecnique. In Vitro equipments were prepared to determination levels of irradited chitosan in the ration. Six levels of irradited chitosan were assigned at without IC, 300 ppm IC, 350 IC, 400 ppm IC, 450 IC and 500 ppm IC, with five replication, respectively. All of data were collected and analized by polynomial orthogonal and contrast orthogonal test, by using SPPS IBM 21. Based on the result in this experiment showed that additional IC of 450 ppm was optimum level for rasing rumen microbes metabolism in the biochemistry proses of fermentabilities and digestibilities at rumen fluid by in vitro.
\end{abstract}

Keywords: Rumen, Irradiated Chitosan, In Vitro 


\section{PENDAHULUAN}

Produktivitas ternak sangat ditentukan oleh faktor eksternak dan internalnya. Optimalisasi faktor internal ternak sesungguhnya merupakan manifestasi dari kemampuan genetik ternak tersebut dalam berekspresi dalam merespon seluruh faktor-faktor lingkungan dan pakan yang dikonsumsinya. Oleh karena itu, tahap pencernaan merupakan tahap yang penting sebelum nutrien tersebut diabsorpsi masuk kedalam darah dan sel-sel.

Bagi ternak ruminansia, fisiologi pencernaannya unik dibandingkan ternak unggas. Ternak ruminansia memeliki rumen yang di dalamnya dikandung sangat banyak species mikroba. Secara parsial, rumen ini adalah sebuah ekosistem yang sangat kompleks (Mushawwir dan Latipudin, 2013) dan secara mandiri harus mampu mempertahankan kondisi idealnya. Kebutuhan serat kasar bagi mikroba rumen adalah sangat esensial. Dalam kenyataannya ternak ruminansia adalah induk semang yang memanfaatkan produk fermentasi dari mikroba sebagai prekursor metabolismenya dalam mendukung pertumbuhan dan produksinya.

Dapat dikatakan bahwa performa ternak ruminansia yang kurang optimal menunjukkan kinerja rumen yang tidak optimal pula. Berbagai penelitian telah dilakukan untuk meningkatkan dan mengoptimalkna fungsional rumen. Penelitian defaunasi hingga rekayasa bahan pakan sebelum dikonsumsi ternak telah banyak dilaporkan. Beberapa kajian menunjukkan belum optimumnya kecernaan bahan pakan meskipun kadar ligninnya telah dikurangi. Hal ini menunjukkan bahwa peran mikroba menduduki fungsi esensial jika dikaitkan dengan kecernaan bahan-bahan organik.

Strategi peningkatan kinerja mikroba perlu terus dikaji dan dilakukan. Pemberian kitosan sebagai feed additif bagi ternak ruminansia juga telah banyak dilakukan. Namun belum menunjukkan hasil yang memuaskan. Salah Satu penyebabnya adalah ukuran molekul kitosan yang mungkin tdak dapat diabsorpsi secara optimal oleh mikroba dan villivilli rumen.

Terkait dengan hal ini, maka dalam penelitian telah dilakukan upaya pengurangan ukuran molekul kitosan, dengan mengaplikasikan teknik radiasi sinar gamma dari nuklir. Berat molekul kitosan yang jauh lebih rendah $<30 \mathrm{kD}$, diharapkan mampu diabsorbsi ke dalam sel-sel mikroba dan mampu mensitimulasi ekpresi gen (atau DNA) mikroba. Ekspresi DNA mikroba yang tinggi diharapakan dapat menghasilkan protein-protein (enzim) yang mampu menginduksi fermentasi protein maupun serat kasar atau secara keseluruhan bahan- 
bahan organik di dalam cairan rumen. Dengan demikian potensi pemanfaatan nutrien bagi ternak semakin tinggi.

Oleh sebab itu peneliti tertarik mangkaji damapk pemberian kitosan hasil iradiasi nuklir terhadap kemampuan fermentabilitas dan kecernaan bahan organik dan kecernaan bahan kering di dalam cairan rumen secara in vitro.

\section{BAHAN DAN METODE}

\section{Bahan dan Alat Penelitian}

Bahan penelitian adalah kitosan iradiasi dalam bentuk liquid. Kitosan hasil radiasi dalam bentuk cairan ini diperoleh dari Pusat Aplikasi Isotop dan Radiasi (PAIR), Badan Tenaga Nuklir Indonesia (BATAN), Pasar Jumat Jakarta. Kitosan terelebuh dahulu diisiolasi dari kulit udang dengan teknik kimiawi untuk memisahkan gugus amin dan mineralnya. Kemudian diiradiasi sinar gamma 75 kilogray (Darwis dkk., 2014). Konsentrasi kitosan induk adalah $5 \%$ atau 50.000 ppm. Larutan tersebut diencerkan sesuai dengan konsentrasi kitosan perlakuan yang telah ditetapkan.

Cairan rumen sapi pasundan untuk proses in vitro diperoleh dari Rumah Potong Hewan (RPH) Banjaran, Kabupaten Bandung. Saliva buatan (larutan McDougall), larutan $\mathrm{HgCl}_{2}$ jenuh, asam borat $\left(\mathrm{H}_{3} \mathrm{BO}_{3}\right)$ berindikator (merah metil/MR dan hijau bromo kresol/BCG), gas $\mathrm{CO}_{2}$, vaselin, $\mathrm{H}_{2} \mathrm{SO}_{4} 0,005 \mathrm{~N}, \mathrm{H}_{2} \mathrm{SO}_{4} 15 \%$, larutan pepsin 0,2 \%, $\mathrm{Na}_{2} \mathrm{CO}_{3}$ jenuh, $\mathrm{NaOH} 0,5 \mathrm{~N}, \mathrm{HCl} 0,5 \mathrm{~N}$, phenolptalein, aquadest, larutan garam formalin (formal saline).

Peralatan penelitian meliputi tabung fermentor, shaker waterbath inkubator, cawan Conway, pipet, buret, labu Erlenmeyer, pendingin Leibig, sentrifuge, tabung sentrifuge, seperangkat alat destilasi, oven $105^{\circ} \mathrm{C}$, cawan porselin, kertas saring, eksikator, timbangan digital dan tanur.

\section{Peubah dan Metode Analisis}

1. Kadar $\mathrm{NH}_{3}$ Cairan Rumen

Teknik Mikrodifusi Conway telah digunakan untuk menentkan Kadar $\mathrm{NH}_{3}$ (General Laboratory Procedure, 1966). $1 \mathrm{~mL}$ supernatan serta $\mathrm{Na}_{2} \mathrm{CO}_{3}$ jenuh juga telah digunakan digunakan dalam pengujian ini, masing-masing ditempatkan di sisi kiri dan kanan cawan Conway. Asam borat dan brom kresol masing-masing sebanyak $1 \mathrm{ml}$, diisikan ke dalam 
sekat tengah cawan. Cawan Conway (berisi $\mathrm{Na}_{2} \mathrm{CO}_{3}$ ) dengan suhu kamar dibiarkan selama 24 jam, setelah ditutup rapat menggunakan vaselin. Untuk menentukan kandungan amonianya, telah dilakukan titrasi menggunakan $\mathrm{H}_{2} \mathrm{SO}_{4}$ 0,005 N. Kadar $\mathrm{NH}_{3}$ ditentukan dengan rumus berikut :

\section{$\mathrm{NH}_{3}=\left(\mathrm{mL}\right.$ titrasi $\left.\times \mathrm{N} \mathrm{H}_{2} \mathrm{SO}_{4} \times 1000\right) \mathrm{mM}$}

Keterangan :

$\mathrm{ml} \quad$ : volume asam sulfat yang terpakai titrasi

$\mathrm{N} \quad$ : Normalitas asam sulfat

2. Kadar Asam Lemak Terbang Total (VFA total)

Kadar Teknik destilasi uap telah digunakan untuk menenutkan kadar VFA sampel (General Laboratory Procedure, 1966). Supernatan yang diperoleh, ditampung dan ditambahkan $1 \mathrm{ml}$ larutan $\mathrm{H}_{2} \mathrm{SO}_{4} 15 \%$, kemudian ditutup dengan rapat. VFA ditampung hingga $300 \mathrm{~mL}$ menggunakan erlemeyer yang berisi $\mathrm{NaOH}$ 0,5 N $5 \mathrm{~mL}$. Dua tetes phenolpthalein telah ditambahkan, kemudian larutan $\mathrm{HCl}$ 0,5 N digunakan sebagai titrator, hingga larutan menjadi bening.

Konsentrasi VFA ditentukan dengan formula berikut :

VFA total $=(b-s) \times N \mathrm{HCl} \times 1000 / 5$

Dimana $\mathrm{b}$ adalah volume titrasi blanko; s adalah volume titran sampel,; dan $\mathrm{N}$ adalah normalitas larutan $\mathrm{HCl}$

3. Pengukuran Kecernaan Bahan Kering dan Bahan Organik in Vitro

Metode Tilley dan Terry (1969) telah digunakan untuk menentukan tingkat kecernaan bahan kering serta bahan organik. Sebanyak $1 \mathrm{~mL}$ larutan kitosan (sesuai perlakuan) dan $1 \mathrm{~g}$ ransum dimasukan dalam tabung fermentor berisi cairan rumen dan larutan saliva buatan (McDougall) masing-masing 10 dan $40 \mathrm{~mL}$, kemudian telah digunakan gas $\mathrm{CO}_{2}$ agar lingkungan lingkungan larutan menjadi anaerob dengan $\mathrm{pH}$ 6,5 - 6,9. Tabung yan gberisi larutan sampel telah diinkubasikan dengan suhu $39^{\circ} \mathrm{C}$ selama 24 jam menggunakan waterbath. $0,2 \mathrm{~mL}$ larutan $\mathrm{HgCl}_{2}$ jenuh telah digunakan untuk mematikan mikroba, kemudian disentrifuse (10.000 rpm; $10 \mathrm{~m})$. $50 \mathrm{~mL}$ pepsisn 0,2\% ditambhkan ke dalam endapan setelah dibuang supernantannya. Larutan diinkubalsi lagi selama 24 jam (suasana aerob). Selanjutnya dengan kertas Whatman 41, endapan disaring. 
Blanko ditetapkan dengan cairan rumen tanpa perlakuan. Koefisien kecernaan BK dan BO dihitung dengan formula:

$$
\begin{aligned}
& \operatorname{KcBK}(\%)=\frac{\text { BK awal }-(\text { BK residu }- \text { BK blanko })}{\text { BK awal }} \times 100 \\
& \operatorname{KcBO}(\%)=\frac{\text { BO awal }-(\text { BO residu }- \text { BO blanko })}{\text { BO awal }} \times 100
\end{aligned}
$$

Keterangan $:$ KcBK = Kecernaan bahan kering; $\mathrm{KcBO}=$ Kecernaan bahan organik

\section{Rancangan Percobaan dan Analisis Data}

Penelitian ini dilaksanakan dengan menggunakan teknik rancangan acak kelompok. Terdiri dari enam (6) perlakuan tanpa dan dengan penambahan kitosan iradiasi dengan tiga (5) ulangan. Keenam perlakuan tersebut, yaitu:

Perlakuan A : Ransum tanpa pemberian kitosan

Perlakuan B : Kitosan iradiasi 300 ppm dalam ransum

Perlakuan C : Kitosan iradiasi 350 ppm dalam ransum

Perlakuan D : Kitosan iradiasi 400 ppm dalam ransum

Perlakuan E : Kitosan iradiasi 450 ppm dalam ransum

Perlakuan F : Kitosan iradiasi 500 ppm dalam ransum

Data fermentabilitas dan kecernaan in vitro yang telah diperoleh kemudian dianalisis dengan teknik statistika menggunakan Uji Polinomial Otrhogonal dan Kontras Orthogonal, serta Uji Korelasi Regresi. Analisis dan interpretasi data telah dilakukan dengan menggunakan software SPSS IBM 21.

\section{HASIL DAN PEMBAHASAN}

Hasil penelitian dan analisis statistika menunjukkan bahwa terdapat pengaruh yang nyata pemberian kitosan iradiasi terhadap fermentabilitas dan kecernaan secara in vitro. Pada Tabel 1, tampak bahwa secara keseluruhan lajur fermentabilitas (VFA dan $\mathrm{NH}_{3}$ ) maupun laju kecernaan, baik bahan kering dan organik menunjukkan peningkatan yang nyata berbeda seriirng dengan penambahan level kitosan iradiasi, hingga 450 ppm dalam 
ransum. Tampaknya pemberian $450 \mathrm{ppm}$ dalam ransum adalah pemberian yang optimal, terutama terhadap KCBK dan KCBO (Tabel 2 dan Gambar 1).

Tabel 1. Pengaruh Chitosan Iradiasi terhadap Fermentabilitasn dan Kecernaan Invitro

\begin{tabular}{lrrrrrr}
\hline \multirow{2}{*}{ Peubah } & \multicolumn{6}{c}{ Kitosan iradiasi dalam ransum (ppm) } \\
\cline { 2 - 7 } & \multicolumn{1}{c}{1500} & \multicolumn{1}{c}{350} & \multicolumn{1}{c}{400} & \multicolumn{1}{c}{450} & \multicolumn{1}{c}{500} \\
\hline VFA (mM/L) & $158,70^{\mathrm{a}}$ & $177,10^{\mathrm{b}}$ & $183,33^{\mathrm{c}}$ & $182,00^{\mathrm{d}}$ & $186,50^{\mathrm{e}}$ & $124,50^{\mathrm{f}}$ \\
$\mathbf{N H}_{3}(\mathbf{m M} / \mathbf{L})$ & $2,32^{\mathrm{a}}$ & $3,70^{\mathrm{b}}$ & $4,20^{\mathrm{c}}$ & $4,55^{\mathrm{d}}$ & $4,40^{\mathrm{d}}$ & $2,65^{\mathrm{e}}$ \\
KCBK (\%) & $51,28^{\mathrm{a}}$ & $53,68^{\mathrm{a}}$ & $56,69^{\mathrm{b}}$ & $60,82^{\mathrm{c}}$ & $64,03^{\mathrm{d}}$ & $62,22^{\mathrm{d}}$ \\
KCBO (\%) & $46,99^{\mathrm{a}}$ & $50,62^{\mathrm{b}}$ & $52,71^{\mathrm{b}}$ & $57,21^{\mathrm{c}}$ & $61,50^{\mathrm{d}}$ & $60,64^{\mathrm{d}}$ \\
\hline
\end{tabular}

Rata-rata perubah yang diikuti dengan abjad yang berbeda menunjukkan perbedaan yang nyata $(\mathrm{P}<0,05)$ $\mathrm{VFA}=$ Volatile fatty acid; $\mathrm{KCBK}=$ Kecernaan bahan kering; $\mathrm{KCBO}=$ Kecernaan bahan organik

Kitosan iriadiasi yang ditambahkan dalam ransum tampaknya mampu meningkatkan kinerja fermentasi oleh mikro-mikroba yang terdapat di dalam cairan rumen (Chiu dkk., 2015; Gwase dkk., 2015). Peningkatan kinerja fermentasi tampak dengan meningkatnya proporsi atau volume VFA dan $\mathrm{NH}_{3}$. Peningkatan VFA menunjukkan bahwa mikroba terutama bakteri di dalam cairan rumen mampu mendegradasi sumber karbohidrat ransum mejadi glukosa (Huang dkk., 2005; Adriani dan Mushawwir, 2008; Araujo dkk., 2015), selanjutnya menjadi prekursor dan menghasilkan VFA dengan volume yang tinggi. Meskipun pada Tabel 2 ditunjukkan koefisien determinasi dan korealsi yang cukup rendah, namun penambahan kitoasan hingga 450 ppm merupakan penambahan yang paling optimal. Pendugaan volume VFA berdasarkan pengaruh kitosan adalah $y=183,10+4,11 x$.

Begitu pula dengan kinerja fermentatif terhadap degradasi protein, ditunjukkan dengan besarnya volume byproduct-nya yaitu kadar $\mathrm{NH}_{3}$ (Jeon dkk., 2003; Kittiwongwattana, 2015; Mushawwir, 2015), menunjukkan alur yang sama dengan VFA, dengan persamaan model pendugaan yaitu y $\left(\mathrm{NH}_{3}\right)=3,23+01,12 x$. Hasil penelitian terdahulu dengan menggunakan kitosan produksi Polymar, Fortaleza Brazil, pada sapi perah dengan dosis 150 $\mathrm{mg} / \mathrm{kg}$ berat badan, menunjukkan peningkatan performa dan efisiensi pemanfaatan nutrient (Valle dkk., 2017). Valle juga melaporkan peningkatan konsentrasi asam lemak rantai panjang dan rantai pendek termasuk kelompok asam-asam VFA. Hasil yang sama juga telah ditunjukkan oleh Kong dkk. (2010) dan . Pada ternak domba, asam lemak terbang propionate menunjukkan peningkatan (Goiri dkk., 2010), Mingoti dkk. (2016), meskipun 
disertai dengan penurunan ammonia dengan bertambahnya konsentrasi pemberian kitosan (Syinowiecki dan Al-Kateeb, 2003; Oresanya dkk., 2008; Pearce dkk., 2013).

Pemberian kitosan, dilaporkan juga telah meningkatkan nitrogen urea darah (blood urea nitrogen $=\mathrm{BUN})$, menurunkan sekresi nitrogen $(\mathrm{N})$ feces tanpa mempengaruhi keseimbangan $\mathrm{N}$ dan sintesis protein oleh mikroba (Mingoti dkk., 2016). Fakta ini berhubungan atau disebabkan bahwa pemberian kitosan mampu meningkatkan kecernaan protein, serta terkait dan berdampak terhadap metabolisme $\mathrm{N}$ di hati.

Hasil penelitian terdahulu menunjukkan juga bahwa bila propionat meningkat, maka produksi metan menurun (Tang dkk., 2005; Xu dan Wang, 2005; Tanuwiria dkk., 2007), sehingga kehilangan energi akan berkurang, dan akan kehilangan energi ini akan minimal bila asam propionat tinggi (Tankson dkk., 2001; Tao dkk., 2006; Soeharsono dkk., 2010; Rhoads dkk., 2013) . Meskipun hasil penelitian ini tidak sepenuhnya sama dengan hasil penelitian sekarang ini dengan penambahan kitosan. Dengan demikian, setiap bahan pakan mempunyai efisiensi tersendiri. Dengan menggunakan teknik stoichiometri maka nilai efisiensi fermentasi bahan pakan yang digunakan lebih akurat (Javaid dkk., 2011; Mushawwir, 2015).

Kitosan iradiasi dengan ukuran berat molekul yang lebih rendah mampu berinterkais langsung ke dalam sel-sel mikroba (Goiri dkk. 2010). Kenyataan ini menunjukkan kinerja mikroba yang lebih baik, meskipun dalam keadaan ekosistem cairan rumen kurang menguntungkan, dengan ketidak seimbangan mineral kation anion (Crini, 2005; Adriani dan Mushawwir, 2008; Nguyen dkk., 2016), cekaman panas lingkungan ekstrernal (Latipudin dan Mushawwir, 2011; Mushawwir dan Latipudin, 2011 dan 2012; Loyau dkk., 2014), profil metabolisme yang tidak seimbang (Mushawwir dkk. 2010 dan 2011; Mushawwir dkk., 2019). Keadaan ini dapat dikurang dengan pemberian kitosan, yang ditandai peningkatan volume VFA dan $\mathrm{NH}_{3}$.

Kecernaan bahan kering (KcBK) dan bahan organik (KcBO) tampaknya mengalami peningkatan $(\mathrm{P}<0,05)$ seiring dengan peningkatan level kitosan iradiasi (Tabel 1 dan Gambar 1). Pengaruh kitosan terhadap kedua indikator kecernaan in vitro tersebut sangat besar, yaitu masing-masing 0,90 dan 0,94, serta model pendugaan masing-masing $\mathrm{KcBK}=49,13$ $+0,57 x$ dan $\mathrm{KcBO}=44,41+3,01 x$ (Tabel 2). 
Tabel 2. Koefisien Deteminasi $\left(\mathrm{R}^{2}\right)$, Koefisien Korelasi (r) Pengaruh Chitosan Iradiasi dan Model Regrasinya terhadap Fermentabiltas dan Kecernaan

\begin{tabular}{|c|c|c|c|}
\hline \multirow{2}{*}{ Peubah } & \multicolumn{3}{|c|}{$\begin{array}{c}\text { Koefisien Deteminasi }\left(\mathbf{R}^{2}\right) \text {, Koefisien Korelasi }(\mathbf{r}) \text { dan Model Pendugaan } \\
\text { Kitosan Iradiasi dalam ransum }\end{array}$} \\
\hline & $\mathrm{R}^{2}$ & $\mathrm{r}$ & Model Pendugaan \\
\hline VFA & 0,10 & 0,32 & $y=183,10+4,11 x$ \\
\hline $\mathbf{N H}_{3}$ & 0,10 & 0,32 & $y=3,23+01,12 x$ \\
\hline КСВК & 0,90 & 0,95 & $y=49,13+0,57 x$ \\
\hline КСВО & 0,94 & 0,97 & $\mathrm{y}=44,41+3,01 \mathrm{x}$ \\
\hline
\end{tabular}

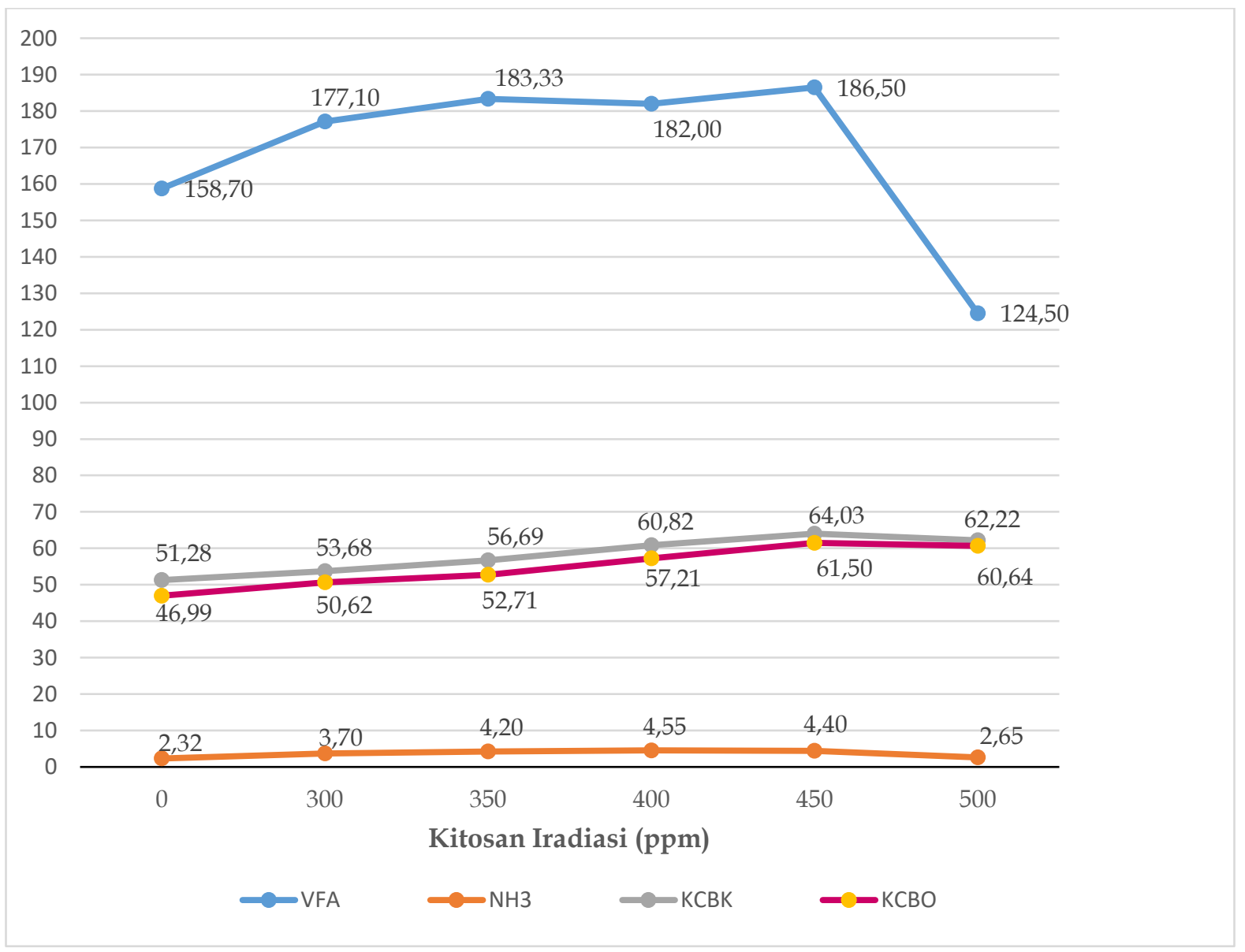

Gambar 1. Profil Fermentabilitas dan Kecernaan dengan Berbagai Level Penambahan Kitosan Iradiasi

Peningkatan kecernaan seiring dengan penambahan level kitosan hingga 450 ppm dalam ransum menunjukkan bahwa terdapat interaksi positif kitosan dengan mikrobamikroba cairan rumen. Berdasarkan beberapa penelitian terdahulu diketahui bahwa setiap 
saat dalam rumen terjadi perubahan-perubahan kimiawi akibat proses fermentasi yang terjadi karena kegiatan mikroorganisme (Gyliene dkk., 2003; Mushawwir dan Latipudin, 2013; Paiva dkk., 2016).

Reaksi kimia yang terjadi dalam rumen sangat bervariasi bergantung kepada bahan makanan yang masuk dan jumlah serta jenis mikroorganisme yang terlibat di dalam proses fermentasi tersebut. Secara garis besar mikroorganisme dalam rumen berfungsi sebagai penyelenggara fermentasi, pembentuk vitamin B kompleks dan vitamin $\mathrm{K}$, sumber zat makanan bagi induk semang. Kemampuan ini meningkat dengan pemberian kirosan (ElSeed dkk., 2002; Goiri dkk., 2010). Sekitar 50\% - 60\% nitrogen yang diperlukan oleh induk semang dapat dipenuhi dari mikroba rumen yang mati. Nilai hayati protein mikroba rumen cukup tinggi, sehingga adanya mikroba dalam rumen sangat penting pada keadaan kadar dan kualitas protein pakan rendah (Renaudeau dkk., 2012; Wiradimadja dkk., 2014). Pada kondisi kadar dan kualitas protein ransum tinggi, seringkali kehadiran mikroba dapat mengganggu (Vie dkk., 2001; Wang dan Zhang, 2004), karena protein pakan tersebut akan dirombak terlebih dahulu oleh mikroba. Kondisi ini sangat merugikan, sehingga banyak peneliti berusaha mencari bahan yang dapat menimbulkan "protein bypass" (Tan dkk., 2010; Tian dkk., 2015).

\section{KESIMPULAN}

Berdasarkan hasil penelitian disimpulkan bahwa kitosan iradasi mampu mempengaruhi fermentabiltas dan kecernaan secara invitro. Pemberian hingga 450 ppm dalam ransum merupakan level yang paling optimum dalam mensimulasi kerja mikro rumen dalam profes biokomiawi fermentasi dan kecernaan di dalam rumen.

\section{DAFTAR PUSTAKA}

Adriani, L. dan Mushawwir, A. 2008. Kadar glukosa darah, laktosa dan produksi susu sapi perah pada berbagai tingkat suplementasi mineral makro. Artkel ilmiah. Fakultas Peternakan Universitas Padjadjaran.

Araujo, A.P.C., Venturelli, B.C., Santos, M.C.B., Gardinal, R., Consolo, N.R.B., Calomeni, G.D., Freitas, J.E., Barletta, R.V., Gandra, J.R., Paiva, P.G., and Renno, F.P. 2015. Chitosan affects total nutrient digestion and ruminal fermentation in Nellore steers. Animal Feed Science and Technology, 206, 114-118. 
Chiu, C.Y., Chan, I.L., Yang, T.H., Liu S.H., and Chiang, M.Y. 2015. Supplementation of chitosan alleviates high-fat diet-enhanced lipogenesis in rats via adenosine monophosphate (amp)-activated protein kinase activation and inhibition of lipogenesis-associated genes. J. Agric. Food. Chem, 63(11), 2979-2988.

Crini, G. 2005, Recent Developments in Polysaccharide-based Materials Used As Adsorbents in Wastewater Treatment. Progress in Polymer Science, 30(1), 38-70.

Darwis, D., Puspitasari, T., Iramani, D., Susilowati, S., dan Pangerteni, D.S. 2014. Preparation of low molecular weight chitosan by radiation and its application for plant growth promoter. IAEA Tecdoc Series: Radiation processed materials in products from polymers for agricultural applications. International Atomic Energy Agenc, 86-98.

El-Seed, A.N.M.A.F., Kamel, H.E.M. ., Sekine, J., Hishinuma, M., and Hamana, K. 2002. Chitin and chitosan as possible novel nitrogen sources for ruminants. Canadian Journal Animal Science, 83(1), 161-163.

Goiri, I., Oregui, L.M., and Garcia-Rodriguez, A. 2010. Use of chitosan to modulate ruminal fermentation of a 50:50 forage-to-concentrate diets in sheep. Journal of Animal Science, $88,749-755$.

Gwaze, F. Rand Mwale, M.. 2015 The Prospect of Duckweed in Pig Nutrition: A Review. Journal of Agricultural Science, 7(11), 189-199.

Gyliene, O., Razmute, I., Taro zaite, R., dan Nivinskiene, O. 2003. Chemical Composition and Sorption Properties of chitosan Produced from Fly larva Shells.Chemija, 14(3), 121-127.

Huang, R. L. , Lin, Y. L., Wu, G. Y Li, ., T. J ., Li, L. L ., Yang, C. B. ., Zhang, J.., Wang, B. ., Deng, Z. Y., Zhang, Y. G.., Tang, Z. R. ., Kang, P. and Guo, Y. M. 2005. Effect of Dietary Oligochitosan Suplementation on Ileal Digestibility of Nutrients and Performance In Broilers. China Agricultural Univ. Press, Beijing, China.

Javaid,A.M, Shahzad, A., Nisa. M., and Sarwar. M. 2011. Ruminal dynamics of ad libitum feeding in buffalo bulls receiving different level of rumen degradable protein. Livestock Science, 135, 98-102.

Jeon, T. I., Hwang, S .G. ., Park, N. G. ., Jung, Y. R.., Shin, S. I., Choi, S. D., and Park, D. K. 2003. Antioxidative effect of chitosan on chronic carbon tetrachloride induced hepatic injury in rats. Toxicology, 187, 67-73.

Kittiwongwattana, C and Vuttipongchaikij, S . 2013. Effect of nutrient media on vegetative growth of Lemna minor and Landoltia punctata during in vitro and ex vitro cultivation. Maejo International J of Sci and Technol. 7(01):60-69

Kong, M., Che, X.G. ., Xing, K.., and Park, H.J. 2010. Antimicrobial properties of chitosan and mode of action: a state of the art review. International Journal of Food Microbialogy 144(1), 51-63.

Latipudin, D. Dan Mushawwir, A. 2011. Regulasi Panas Tubuh Ayam Ras Petelur Fase Grower dan Layer. Jurnal Sains Peternakan Indonesia, 6(2), 77-82.

Loyau, T., S. Metayer-Coustard, S., Berri, C., Crochet, S., Cailleau-Audouin, E.., Sannier, M., Chartrin, P., Praud, C., Hennequet-Antier, C., Rideau, N., Courousse, N., MignonGrasteau, S., Everaert, N., Duclos, M.J., Yahav, S., Tesseraud, S., and Collin, A. 2014. Thermal manipulation during embryogenesis has longterm effects on muscle and liver metabolism in fast-growing chickens. PLoS One, 9(9), e105339.

Mingoti, R.D., Freitas, J.E., Gandra, J.R., Gardinal, R., Calomeni, G.D., Barletta, R.V., Vendramini, T.H.A., Paiva, P.G., and Renno, F.P. 2016. Dose response of chitosan on nutrient digestibility, blood metabolites abd lactation performance in Holstein dairy cows. Livestock Science, 187, 35-39. 
Mushawwir A. dan Latipuddin, D. 2013. Biologi Sintesis Telur, perspektif Fisologi, Biokimia dan Molekuler Produksi Telur. Penerbit Graha Ilmu, Yogyakarta.

Mushawwir, A. 2015. Biokimi Nutrisi. Widya Padjadjaran, Bandung.

Mushawwir, A. Dan Latipudin, D. 2011. Beberapa Parameter Biokimia Darah Ayam Ras Petelur Fase Grower dan Layer dalam Lingkungan “Upper Zonathermoneutral. Jurnal Peternakan Indonesia, 13(3), 191-198.

Mushawwir, A. dan Latipudin, D. 2012. Respon fisiologi thermoregulasi ayam ras petelur fase grower dan layer. Proseding seminar zootechniques for Indogeneous resources development, ISAA Fakultas Petenakan Universitas Diponegoro. Proceeding of National Seminar on Zootechniques, 1(1), 23-27.

Mushawwir, A., Adriani, L., and Kamil. K.A. 2011. prediction models for olfactory metabolic and sows \%rnareticulocyt (rnart) by measurement of atmospheric ammonia exposure and microclimate level. Journal of the Indonoseain Tropical Animal Agriculture, 36, 14-20.

Mushawwir, A., Suwarno, N., dan Yulianti, A.A. 2019. profil malondialdehyde (MDA) dan kreatinin itik fase layer yang diberi minyak atsiri garlic dalam kondisi cekaman panas. Jurnal Ilmu dan Industri Peternakan, 5(1), 1-11.

Mushawwir, A., Yong, Y.K., Adriani, L., Hernawan, E., and Kamil, K.A. 2010. the fluctuation effect of atmospheric ammonia $\left(\mathrm{NH}_{3}\right)$ exposure and microclimate on hereford bulls hematochemical. Journal of the Indonesian Tropical Animal Agriculture, 35, 232-238.

Nguyen, T.T., Bowman, P.J., Haile-Mariam, M., Pryce, J.E., and Hayes, B.J. 2016. Genomic selection for tolerance to heat stress in Australian dairy cattle. Journal of Dairy Science, 99, 2849-62.

Oresanya, T. F., Beaulieu, A. D., and Patience, J. F., 2008. Investigations of energy metabolism in weanling barrows: The interaction of dietary energy concentration and daily feed (energy) intake. Journal of Animal Science, 86, 348-363.

Paiva, P.G., de Jesus, E.F., Valle, ., T. A. D., del Almeida, G. F., Costa, A.G.B.V.B., Consentini, C.E.C., F.Zanferari, F., Takiya, C.S., da Silva Bueno, I.C., and Renno, F.P., 2016. Effects of chitosan on ruminal fermentation, nutrient digestibility, and milk yield and composition of dairy cows. Animal Production Science, 53, 231-236.

Pearce, S. C., Gabler, N. K., Ross, J. W., Escobar, J., Patience, J. F., Rhoads, R. P., and Baumgard, L. H., 2013. The effects of heat stress and plane of nutrition on metabolism in growing pigs. Journal of Animal Science. 91(5), 2108-2118.

Renaudeau, D., Collin, A., Yahav, S., De Basilio, V., Gourdine, J. L., and Collier, R. J. 2012. Adaptation to hot climate and strategies to alleviate heat stress in livestock production. Animal 6, 707-728.

Rhoads, R.P., Baumgard, L. H., and Suagee, J. K., 2013. Metabolic priorities during heat stress with an emphasis on skeletal muscle. Journal of Animal Science, 91, 2492-2503.

Soeharsono., Adriani, L., Kamil, K.A., Hernawan, E., dan Mushawwir, A. 2010. Fisiologi Ternak: Fenomena dan Nomena Fungsi Jaringan dan Organ pada Hewan. Widya Padjadjaran.

Syinowiecki, J and Al-Kateeb, N . 2003. Production properties and some new application of chitin and its derivatives. Critical reviews in food science and nutrition. Pro Quest Medical Library, 43(2), 145:171

Tan, G.Y., Yang, L., Fu, Y.-Q., Feng, J.H., and Zhang, M.H., 2010. Effects of different acute high ambient temperatures on function of hepatic mitochondrial respiration, antioxidative enzymes, and oxidative injury in broiler chickens. Poultry Science, 89, 115-122. 
Tang, Z.R., Yin, Y.L., Nyachoti, C.M., Huang, R.L., Li, T.J., Yang, C.B., Yang, X.J., Gong, J., Peng, J., Qi, D.S., Xing, J.J., Sun, Z.H., and Fan, M.Z. 2005. Effect of dietary supplementation of chitosan and galacto-mannan-oligosaccahride on serum parameters and the insulin like factor-I mRNA expression in early-weaned piglets. Domest. Anim. Endrocrinol. 28:430-441.

Tankson, J. D., Vizzier-Thaxton, Y., Thaxton, J. P., May, J. D., and Cameron, J. A., 2001. Stress and nutritional quality of broilers. Poult. Sci. 80:1384-1389.

Tanuwiria, U.H., Mushawwir, A. dan Yulianti, A. 2007. Potensi pakan serat dan daya dukungnya terhadap populasi ternak ruminansia di wilayah kabupaten garut. Jurnal Ilmu Ternak, 7(2), 117-127.

Tao, X., Zhang, Z. Y., Dong, H., Zhang, H., and Xin, H. 2006. Responses of thyroid hormones of market-size broilers to thermoneutral constant and warm cyclic temperatures. Poultry Science, 85,1520-1528.

Tian, H., Wang, W., and Zheng, N. 2015. Identification of diagnostic biomarkers and metabolic pathway shifts of heat-stressed lactating dairy cows Journal of Proteomics, 125, 17-28.

Valle, T.A., Paiva, P.G., Jesus, E. F., Almeida, G.F., Zanferari, F., Costa, A.G.B.V.B., Bueno, I.G.S., and Renno, F.P. 2017. Dietary chitosan improves nitrogen use and feed conversion in diets for mid-lactation dairy cows. Livestock Science, 201, 22-29.

Wang, S. Q., and Zhang, C. S., 2004. Chitin, chitosan and their application in aquaculture. Feed Research, 5, 25-28.

Wiradimadja, R., Rusmana, D., Widjastuti, T., and Mushawwir, A., 2014. Chicken slaughterhouse waste utilization (chicken feather meal treated) as a source of protein animal feed ingredients in broiler chickens. Lucrări Științifice - Universitatea de Științe Agricole și Medicină Veterinară, Seria Zootehnie, 62, 120-124.

Xie, W., Xu, P., and Liu, Q. 2001. Antioxidant activity of watersoluble chitosan derivatives. Bioorganic \& Medical Chemistry Letter, 11(13), 1699-1701.

Xu, Y.Q. and Wang, Y.Z. 2005. The application of chitin in aquaculture. China Feed. 7, 30-32. 